\title{
くシンポジウムI $>$
}

\section{抗リン脂質抗体症候群と Trousseau 症候群}

\author{
内山真一郎 赫 洋美 清水 優子 \\ 橋本しをり岩田誠 \\ 東京女子医科大学医学部神経内科
}

Key words : 若年性脳卒中, 覀性腫瘍, 血液凝固マーカー, 抗血栓療法, ガイドライン

(脳卒中 $27: 547-552,2005$ )

厚生労㗢省循環器病委託研究事業 (12 指-2)「若年世 代の脳卒中の診断, 治療, 予防戦略に関する全国多施 設共同研究」の成果として刊行された「若年性脳卒中 診療の手引き」の中で著者らは「血液凝固異常症によ る脳梗塞の診断と治療の手引き」を発表した1).この手 引きにおいて血液凝固異常症の原因として挙げた疾患 の中でも抗リン脂質抗体症候群 (APS) と Trousseau 症候群は比較的頻度の高い疾患として臨床的に重要で ある. 本稿では, 両疾患の概念, 病因, 病態, 診断基 準, 臨床特徵, 血液学的所見, 放射線学的所見, 治療 指針について自験例を交えて概説する.

\section{抗リン脂質抗体症候群}

1. 診断基準

APS の診断基準としては 1998 年に発表された Sap- poro criteria が用いられている(表 1) 2).この診断基準 は臨床診断基準と検査診断基準から構成されている. 臨床診断基準としては血栓症と妊娠異常が取り上げら れている. 血栓症は, 動脈・静脈・小血管の血栓症を 画像, 超音波, 組織病理のいずれかで証明することと し，血栓症が血管炎なしに存在することを強調してい る。妊娠異常は, 胎児死亡, 流産, 早産の定義が明確 に述べられている.検查診断基準では, $\beta_{2} \mathrm{GPI}$ 依存性の 抗カルジオリピン抗体 (ACA) とループスアンチコア グラント（LA）を国際血栓止血学会のガイドラインに したがって測定し，6 週間の間隔で 2 回以上陽性であ ることとしており，ACAに関しては中等度または高 度の抗体価を示すこととしている.確実な APSとして は，臨床診断基準と検査診断基準の少なくとも一つず つを満たすこととしている。

表 1 抗リン脂質抗体症候群の診断基準 (Sapporo Criteria, 1998) 1)2)

\section{臨床診断基準}

1. 血栓症

あらゆる組織や臓器の動脈, 静脈, 小血管の血栓症

表在静脈血栓症を除き画像, 超音波, 組織病理のいずれかで証明

病理学的には血栓症が血管炎なしに存在する必要がある

2. 姃娠異常

(1) 正常胎児の 10 週以後の 1 回以上の説明不能の死亡

(2) 正常胎児の 34 週以前の高度の前子疭, 子痡, 胎盤不全による 1 回以上の早産

（3）母親の解剖学的・ホルモン的異常や父親と母親の染色体異常が除外された，10 週以後の連続 3 回以上の説明不 能の流産

検查診断基準

1. B2-glycoprotein 依存性抗カルジオリピン抗体に対する標準的な ELISA 法により，IgG・IgM isotypeの一方また は両者の抗カルジオリピン抗体が 6 週間以上の間隔で 2 回以上, 中等度ないし高度の抗体価を示す。

2. 国際血栓止血学会 (ループス・アンチコアグラントノリン脂質依存性抗体学術委員会) のガイドラインにしたがっ て6 䓢間以上の間隔で 2 回以上血嶈中にループス・アンチコアグラントが検出される.

確実な抗りン脂質抗体症候群は臨床診断基準の少なくとも1つと検查診断基準の1つを満たした場合に診断される. 
しかしながら，抗りン脂質抗体（APL）にはACA やLA 以外にも多くの抗体が知られており，これらの 抗体がAPSの原因になることも少なくない(表 2). し たがって，血栓症と妊娠異常を合併するような，APS が強く疑われる症例では, ACA や LA が陰性であって も APS は否定できないので抗ブロトロンビン抗体や 抗フォスファチジールセリン抗体などの APL をでき るかぎり測定すべきである。

\section{2. 血栓形成機序}

APSは血栓形成と凝固時間延長という正反対の現 象が並存する不思議な病態である。 Rand $ら^{33}$ は, この 一見矛盾した二つの現象を初めて同時に説明しうる 「アネキシンVシールド分断説」を提唱し，血栓止血学 の分野にセンセーションを巻き起こした．彼らの作業 仮説によれば，APLの非存在下でアネキシン V は陰 性荷電リン脂質膜に結合して膜表面を覆いプロトロン ビナーゼ複合体の形成を阻害して凝固活性化を抑制す るが，アネキシン V の非存在下では APL が陰性荷電 リン脂質への凝固因子のアクセスを妨げるため凝固時 間が延長する(LA 効果)。一方，アネキシンV の 存在 下では，APL は直接，あるいはリン脂質のコファタ ター蛋白 (B2GPI) との相互作用を介してリン脂質膜上 のアネキシンV V シールドを分断することにより凝固 反応に利用される陰性荷電リン脂質量を増加させるた め凝固を活性化して血栓形成を促進するという（図 1).

\section{3. 臨床特徽}

我々は脳梗塞で当科に入院した APL 陽性連続 40 症例を同時期に入院したAPL 陰性の脳梗塞連続 40 症例と比較しだ)。その結果, APL 陽性脳梗塞患者は, (1) 若年発症しやすく (49.6 歳対 66.2 歳, $\mathrm{p}=0.0001)$ ， 女性に多い (28 例対 15 例, $\mathrm{p}=0.007)$ ，(2) 心臟弁膜症 の合併が多い $(61 \%$ 対 $13 \%, p=0.0001),(3)$ 脳梗塞の 一般的な危険因子（高血圧, 糖尿病, 高脂血症) が少 ない (1.00 対 1.65, $\mathrm{p}=0.007),(4)$ てんかん, 春髄炎, 片頭痛などの神経疾患 $(45 \%$ 対 $0 \%, p=0.0001)$ ，血液 凝固異常症 (凝固阻止因子欠乏症, 血小板減少症) (30\% 対 $8 \%, \mathrm{p}=0.022)$ および静脈血检症 $(15 \%$ 対 $0 \%, \mathrm{p}=$ 0.034)の合併が多い, (5) トロンビン・アンチトロンビ ン III 複合体（TAT）が低值を示す（5.8対 6.6, p= 0.012),（6）相対的に椎骨脳底動脈系の梗塞が多い（内 䁰動脈系 $53 \%$ 対 $83 \%, p=0.009),(7)$ 大血管病変の合 併が少ない (35\% 対 $85 \%, \mathrm{p}=0.038)$ ，が特徴として挙 げられた。臓弁膜症の合併が多いのは，APLにより
表 2 Sapporo Criteriaに規定されていない抗リン脂 質抗体関連自己抗体（国際血栓止血学会標準化小委 員会,ボストン,2002)
1) 抗 $\beta 2 \mathrm{GPI}$ 抗体
2) 抗プロトロンビン抗体
3) 抗プロテインC抗体
4) 抗ブロテインS抗体
5) 抗プラスミノゲン抗体
6) 抗アネキシン抗体
7) 抗 von Willebrand 因子抗体

心内血栓形成が促進する可能性と, APL 自身が心臓弁 膜症の原因となる可能性の雨者が考えられる.TAT の低值に関しては，通常脳梗塞急性期では TAT が高 值を示しゃすいが，TATの形成阻害による遊離卜ロ ンビン量の増加が APSの血栓形成機序の一つとして 提唱されていることと関係している可能性が示唆され る.椎骨脳底動脈系の梗塞が多い理由は不明であるが, 内䅡動脈系との血行動態や血管構築の相違が関与して いるのかもしれない.

\section{4. 治療}

脳卒中治療ガイドライン 2004 では, (1) APL 陽性者 の脳梗塞の再発予防に，第一選択としてワルファリン が使用されるが，十分は科学的根拠がない，(2) APL 陽性者の脳梗塞の再発予防において全身性エリテマ トーデス (SLE) 合併例では副腎皮質ステロイドが推奖 される，と記載されているが，いずれも推奖の強さは C1（行うことを考慮してもよいが，十分な科学的根拠 はない）であり，エビデンスレベルは低い，

英国血液学会のガイドライン 值とし，2.0〜3.0を至適強度とした長期のワルファリ ン療法が推奨されており, 標準的強度のワルファリン で再発を生じた場合には INR 3.5 のワルファリン療法 が正当化されるが，ワルファリンとアスピリンの併用 効果は不明であり，出血合併症増加も考慮する必要が あるとしている。

Jacobs と Levine は, APL 陽性の脳梗塞や TIA の再 発予防には INR 2 3の短期間の抗凝固療法が推奖さ れるが, 明らかな心内塞栓源がなければ抗血小板療法 でもよいとしており，抗㠜固潦法の場合でも再発がな くAPLのレベルが低下すれば抗血小板療法に切り替 えるとしている (Current Treat Options Neurol 2: $449-58,2000)$.

非心原性脳梗塞 2,000 例を対象としてワルファリン 


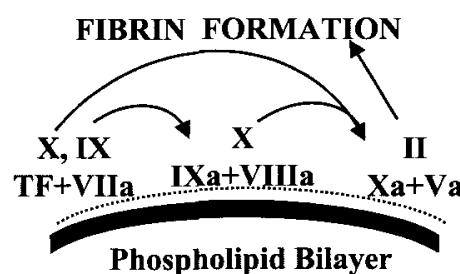

A

(一) Annexin-V

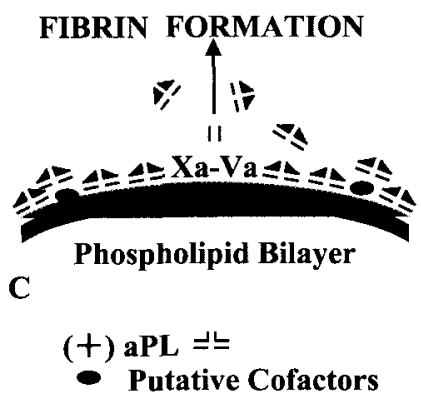

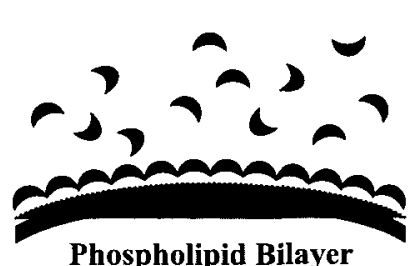

B

Phospholipid Bilayer

(+) Annexin-V

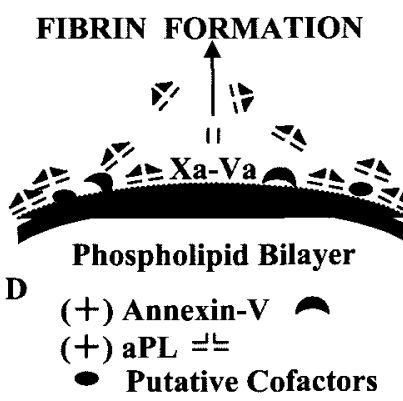

图 1 抗リン脂質抗体によるアネキシンV 抗血栓シールド分断機序の作業仮説 ${ }^{37}$ (A) 陰性荷電リン脂質は細胞膜二重層表面に発現すると 3 つの異なる凝固複合体形成 の强力なコファタターとして作用し, 血液凝固を促進する. (B) 抗りン脂質抗体 (APL) 非存在下でアネキシン $\mathrm{V}$ は陰性荷電リン脂質膜表面に集合してシールド状に覆って 凝固反応を抑制する. (C) アネキシン V 非存在下で APL は陰性荷電りン脂質への凝 固因子のアクセスを妨げることにより凝固時間を延長する（ループスアンチコアグラ ント効果). (D) アネキシン V 存在下では, APL が面接あるいはリン脂質コファクター

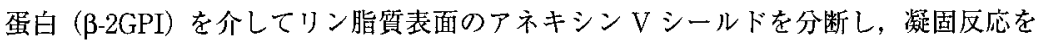
惹起する陰性荷電りン脂質量を增加させることにより血栓形成を促進する.

（INR 1.4〜2.8）とアスピリン（325mg/日）の再発予防 効果を比較したWarfarin Aspirin Recurrent Stroke Study（WARSS）のサブスタディーとして行われた Antiphospholipid Antibody Stroke Study (APASS) に よれば，ACA 陽性群のサブ解析ではワルファリン投 与群とアスピリン投与群の再発率は有意差がなかっ $た^{6}$.

最近発表された AHA/ASAのガイドラインでは, APL陽性の潜因性虚血性脳卒中 (cryptogenic stroke) ・TIA 患者には抗血小板療法が推奨される が, 多臟器の静脈・動脈血栓症や網状皮斑を伴い, APS の診断基準を満たす虚血性脳卒中・TIA患者には INR 2 3の抗凝固療法が推奖されている7).

\section{Trousseau 症候群}

1. 概念と原因

Trousseau 症候群は, 潜在性の悪性腫瘍の遠隔効果 (remote effect)により神経症状を生じる傍悪性腫痬神 経症候群 (paraneoplastic neurologic syndrome) の一つであり, 忢性腫瘍に伴う血液凝固圥進により脳卒中 症状を生じる病態である ${ }^{8}$. 脳は凝固外因系の引き金 となるトロンボプラスチンが豊富で，トロンビンの拮

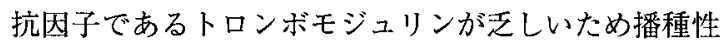
血管内凝固異常症 (DIC)の標的臟器となりやすい。脳 梗塞の成因の多くはDIC に併発した非細菌性血栓性 心内膜炎 (NBTE) に上る心原性脳塞栓症と考えられる が, 最近では深部静脈血栓症を併発した卵冈孔開存に よる奇異性脳塞栓症が原因と考えられる症例の報告も 増加している，その他の原因としては，血管内凝固に よる微小血栓 - 塞栓, 細菌性塞栓, 腫湯塞栓, 脳静脈 静脈洞血栓症が挙げられる. 原因となる悪性腫瘍は固 形癌が多く，その中では婦人科的腫瘍が最も多い.

2. Trousseau 症候群の起源

Armand Trousseau は Trousseau 徵候などで有名 


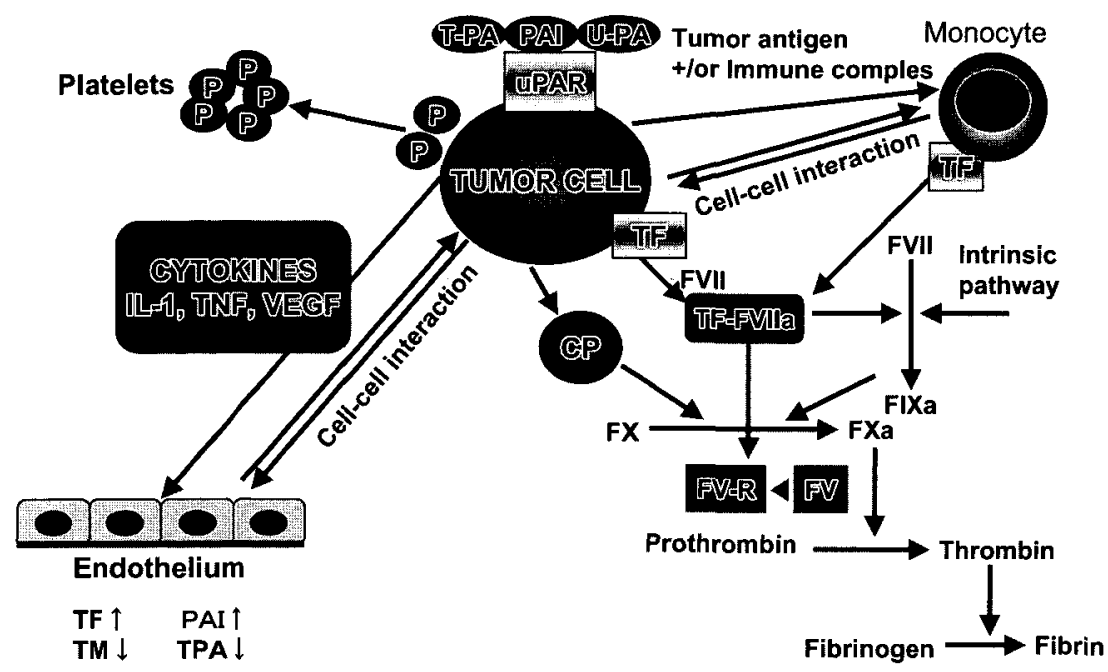

図 2 腫瘍細胞と凝固系との相互作用経路 ${ }^{10}$

腫湯細胞は凝固カスケードを活性化する細胞性プロコアグラント, 線溶蛋白とそのイ ンヒビターおよび受容体を発現する、また，各種けイトカインを放出して内皮練胞を 抗血栓性から血栓性に変える。さらに，腫瘍細胞は直接または可溶性メディエーター を介して内皮細胞，単球，血小板との相互作用を発揮する.

なフランスの神経内科医であり，1850 年に Hotel Dieu の主任医師となっだ．彼は有名な教科書で知られる 連続講義の中で血栓症と癌を合併した 3 症例を紹介 し, 反復性または特発性の血栓塞栓症では癌を検索す る必要があり，その病態生理は機械的圧迫ではなく， 止血機構の変化にあることを示唆した. 1867 年 1 月 1 日に彼は自らの下肢に深部静脈血栓を生じたことに気 付き，自身の病態を祭知して絶望したことを記載して おりわずか数力月後に胃癌で死亡した。このように, Trousseau 症候群ほど最初の報告者の名を冠するにふ さわしい症㵀群はないように思われる.

3. 腫瘍細胞による凝固活性化機序

腫瘍細胞による凝固活性化機序は複雑であるが，多 くの研究者の努力によりかなり詳細な機構の解明が進 んでいる (図 2) ${ }^{100}$. 腫瘍細胞は凝固カスケードを活性 化する組織因子，腫場プロコアグラント，第 V 因子受 容体などの細胞性プロコアグラントや線溶蛋白, 線溶 インヒビターおよびそれらの受容体を発現するととも に, 各種サイトカインや腫瘍抗原とその免疫複合体を 介して血小板, 単球, 内皮細胞との細胞間相互作用を 惹起してさらに凝固活性化を促進し，血栓形成をもた らすと考えられる。
4. Trousseau 症候群の臨床的特徵

当科で経験したTrousseau 症候群 8 症例の臨床的 特徵は, (1) 年㱓は $27 \sim 70$ 歳と幅があり, 男性 2 例, 女性 6 例々女性に多い, (2) 癌の種類は卵巣癌 3 例, 子 宮体癌 2 例, 前立腺癌 1 例, 胆管癌 1 例, 不明 1 例と婦 人科系の固形癌が多い,(3) 梗塞部位は皮質 6 例，皮質 下 1 例，なし 1 例（TIA）と皮質に多い，(4) 梗塞数は 9 個 1 例, 4 個 1 例, 2 個 1 例, 1 個 4 例, 0 個 1 例 (TIA) と多発しやすい, (5) 脳梗塞の性状は出血性梗塞 2 例, 筫血性梗塞 5 例，梗塞なし 1 例 (TIA) とさまざまであ り，(6) 血小板数は 10 万 $/ \mathrm{mm}^{3}$ 未満 2 例, 10 万 $/ \mathrm{mm}^{3}$ 以上 6 例，フィブリノーゲンも低下 1 例, 正常 5 例, 上昇 2 例と代償されている慢性 DIC の症例が多い, (7) FDP，TAT，Dダイマーはいずれも上昇 5 例，未 測定 3 例であり，測定しえた全例で上昇しており，こ れらの凝固マーカーの測定は診断にきわめて有用であ る，(8) 队トロンボグロブリンと血小板第 4 因子は上昇 4 例, 正常 1 例, 未測定 3 例であり, 上昇例が多い, と いう結果であった。

\section{5. 治療}

予後をもっとも左右するのは原疾患の治療の成否で あり，早期診断・早期治療が命運を握る ${ }^{1}$. 抗凝固療法 の適応があり，ヘパリンが第一選択となるが，長期化 
する場合には低分子ヘパリンやへパリノイドの皮下注 が有用である．血小板や凝固因子の消費による出血傾 向が高度な場合には血小板 3 万 $/ \mathrm{mm}^{3}$ 以上，フィブリ ノーゲン $75 \mathrm{mg} / \mathrm{dL}$ 以上を目標に補充療法の適応があ る。抗凝固薬の併用なしに補充療法を行うと血栓形成 傾向が高まるので，抗凝固薬を併用するのが原則であ る.

固形癌で過剩発現している組織因子は凝固カスケー ドを活性化するのみならず，癌の成長，血管新生，転 移を促進することが知られている（J Cell Biol 140： 1241一53, 1998)。抗凝固療法の効果に関連して, 低分子 ヘパリンは抗血管新生作用があり，担癌動物モデルで アポプトーシスを誘導することや (Cancer Res 60: 6196-200, 2000)，ヘパリンがインテグリン依存性の細 胞接着を抑制して細胞間相互作用を抑制することによ り癌転移を抑制するなどが報告されている (PNAS 98： 3352-3357, 2001). Fragmin Advanced Malignancy Outcome Study（FAMOUS）では進行した固形癌 385 例にダルテパリン 5,000 単位かプラセボを投与し，1 年間追跡調查したところ，低分子へパリン群で著明に 生存率が改善したという成績が示されている（J Clin Oncol 22:1944-1948, 3004).

\section{文献}

1）内山真一郎：血液凝固異常症による脳梗塞の診断 と治療の手引き, 矢坂正弘編, 若年者脳卒中診療の 手引き, 循環器病研究委託費 12 指 -2 若年世代の 脳卒中の診断, 治療, 予防戦略に関する全国多施設 共同研究 (主任研究者: 峰松一夫), 大阪, 国立循 環器病センター内科脳血管部門, 2003, pp313一-317

2) Wilson WA, Gharavi AE, Koike T, et al. : International consensus statement on preliminary classi- fication criteria for definite antiphospholipid syndrome. Arthritis Rheum 42 : 1309-1311, 1999

3) Rand JH, Wu XX : Antibody-mediated disruption of annexin $\mathrm{V}$ antithrombotic shield: A new mechanism of thrombosis in the antiphospholipid syndrome. Thromb Haemost $82: 649-655,1999$

4) Terashi H, Uchiyama S, Hshimoto S, et al. : Clinical characteristics of stroke patients with antiphospholipid antibodies. Cerebrovasc Dis 19 : $384-390,2005$

5) British Society of Haematology: Guidelines on the investigation and management of the antiphopholipid syndrome. Br J Haematol 109 : 704-715, 2000

6) Levine SR, Brey RL. Tilly BC, et al, for the APASS Investigators : Antiphospholipid antibodies and subsequent thrombo-occlusive events in patients with ischemic stroke. JAMA $291: 576-$ 584,2004

7) Sacco RL, Adams R, Albers G, et al: Guidelines for prevention of stroke in patients with ischemic stroke or transient ischemic attack. A statement for healthcare professionals form the American Heart Association/American Stroke Association Council on Stroke. Stroke 37:577-617,2006

8）内山真一郎，清水優子：悪性腫瘍患者にみられる 脳梗塞 (Trousseau 症候群)。特集：悪性腫瘍と大 脳病変. 神経内科 $58: 463-467,2003$

9) Khorana AA : Maligancy, thrombosis and Trousseau : The case for an eponym. J Thromb Heamost $1: 2463-2465,2003$

10) Falanga A, Rickles FR : Pathophysiology of the thrombophilic state in the cancer patient. Sem Thromb Hemost 25 : 173-182, 1999 


\title{
Abstract \\ Antiphospholipid syndrome and Trousseau's syndrome
}

\author{
Shinichiro Uchiyama, M.D., Hiromi Terashi, M.D., Yuko Shimizu, M.D., \\ Shiori Hashimoto, M.D. and Makoto Iwata, M.D. \\ Department of Neurology, Tokyo Women' Medical University School of Medicine
}

Antiphospholipid syndrome (APS) and Trousseau's syndrome are clinically important because they are common among coagulation abnormalities as causes of cryptogenic stroke or stroke in young adults, and are treatable with antithrombotic therapy.

Antiphospholipid antibodies (APLs) such as antiphosphatidyl serine or antiprothrombin antibody other than anticaldiolipin antibody or lupus anticoagulant should be measured in patients strongly suspected of APS. Disruption of annexin V shield by APLs is the first hypothesis to simultaneously explain prolongation of coagulation time and thrombophilia in APS patients. In our stroke patients with APLs, females are more common, stroke occurs earlier and preferentially involves vertebrobasilar system, and valvular heart diseases, neurological diseases, coagulation abnormalities, and venous thrombosis are frequent, but vascular risk factors and large vessel lesions are less frequent, and levels of thrombin-antithrombin III complex are lower.

Trousseau's syndrome is a paraneoplastic neurologic syndrome which is caused by remote effects of cancers. Tumor cells express cellular procoagulants and fibrinolytic proteins as well as their inhibitors and receptors. They also release cytokines and interact with endothelial cells, monocytes and platelets to further enhance activation of coagulation cascade. Clinical characteristics of our patients with Trousseau's syndrome are at wide range of age, female-predominant, commonly associated with solid gynecological cancers, frequently suffer from multiple bland or hemorrhagic cortical infarcts, usually associated with compensated platelet counts and fibrinogen levels, and always associated with increased levels of coagulation and fibrinolysis markers.

(Jpn J Stroke $27: 547-552,2005)$

Key words : stroke in young adults, cancer, hemostatic markers, antithrombotic therapy, guidelines 